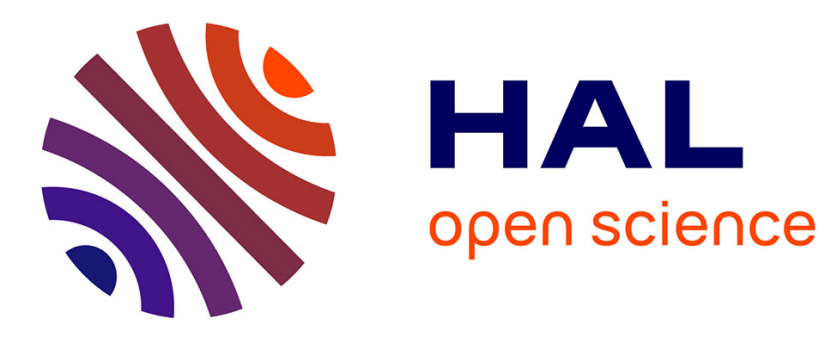

\title{
Nuclear DNA content in water buffalo
}

\author{
A. Salerno, A. Varchetta, G. Delle Donne
}

\section{To cite this version:}

A. Salerno, A. Varchetta, G. Delle Donne. Nuclear DNA content in water buffalo. Annales de génétique et de sélection animale, 1982, 14 (1), pp.110-110. hal-00893410

\section{HAL Id: hal-00893410 https://hal.science/hal-00893410}

Submitted on 1 Jan 1982

HAL is a multi-disciplinary open access archive for the deposit and dissemination of scientific research documents, whether they are published or not. The documents may come from teaching and research institutions in France or abroad, or from public or private research centers.
L'archive ouverte pluridisciplinaire HAL, est destinée au dépôt et à la diffusion de documents scientifiques de niveau recherche, publiés ou non, émanant des établissements d'enseignement et de recherche français ou étrangers, des laboratoires publics ou privés. 


\title{
Relationship between blood attributes and predicted breeding value for milk yield in calves \\ H. NIEDERMAIER, W. GRÄNZER, W. GROTH, K. RUHLAND, H. EICHINGER and F. PIRCHNER \\ Institut für Tierwissenschaften an der Technischen Universität München, 8050 Freising-Weihenstephan
}

The change of glucose, enzymes (GOT, LDH) and metabolites (free fatty acids, urea, lactat) in blood serum of 40 male Simmental calves was investigated during a 48 hours starvation period. During starvation period the concentration of glucose decreased from $3.71 \pm 0.06 \mathrm{mmol} / 1$ to $2.16 \pm 0.05 \mathrm{mmol} / 1$. We observed an increase of GOT- and LDH activity in blood serum with increasing starvation time. Calves with high predicted breeding value for milk yeild showed before, during and after the starvation period lower GOT- and LDH-activity than beef calves with a significant lower predicted breeding value for milk yield. The concentration of urea in blood serum increased during the starvation period. The concentration of free fatty acids in blood serum changed slightly but without definite pattern. Surprisingly, calves with different predicted breeding value for milk yield displayed before and after starvation periods nearly the same concentration of free fatty acids, but during the starvation period varying concentrations.

\section{Nuclear DNA content in water buffalo}

\author{
A. SALERNO, A. VARCHETTA and G. DELLE DONNE \\ C.N.R., Operative Unit on "Chromosomal Polymorphism» \\ Naples University, Faculty of Agriculture, Zoognostic Chair, 80055 Portici, Italy
}

Scanning microdensitometry has been used to measure the nuclear DNA content in water buffalo lymphocytes. The technique is exquisitely sensitive and allows the detection of individual differences, both among and within animals, that aren't resolved by any other current method.

The trial was carried out on 2965 isolated nuclei from buffalo lymphocytes of 20 animals, with two groups of 10 males and 10 females for each one, and DNA content was measured with the Feulgen reaction, using Zeiss Scanning Microscope Photometer SMP 01. All measurements were made at a wavelength of $560 \mathrm{~nm}$, employing $100 \times$ objective.

On the total number of observed lymphocytes, the modal class was 0.200 , the average of the nuclear DNA content was $0.20438 \pm 0.021$ (c.v. $\%=12 \mathrm{p} .100$ ) ; the sex difference was $0.00574(t=7.4545 ; \mathrm{p}<0.001)$.

The origin of the variation in nuclear DNA content was critically evaluated in relation : (a) to the adaptive mechanisms by which the environment induces genetic changes as it may occur in natural conditions, and (b) to the variety of distributional patterns and variable amounts of constitutive heterochromatin ( $\mathrm{C}$ band) in the chromosomes. 